\title{
Economic Effects of Renewable Energy Technologies
}

\author{
Dario Maradin \\ University of Rijeka, Faculty of Economics, Croatia \\ dmaradin@efri.hr

\section{Ljerka Cerović} \\ University of Rijeka, Faculty of Economics, Croatia \\ cerovic@efri.hr \\ Trina Mjeda \\ University North, Croatia \\ trina.mjeda@unin.hr
}

\begin{abstract}
Rapid economic development has resulted in the more frequent use of renewable energy technologies. On the other hand, the production and use of renewables fosters the development of new technologies, creating many new opportunities for entrepreneurial-minded individuals and, consequently, the economy in general. Renewable energy technologies have a multiplier effect in spurring the economy and the development of not only the energy sector but also all the supporting activities related to such industry. The purpose of this research is to analyse both the positive and the negative economic effects of investing in various renewable technologies, as well as to confirm, by means of the energy-economy model, the benefit of such technologies in boosting the economy.
\end{abstract}

Keywords: renewable energy sources, new technologies, boosting the economy

\section{Introduction}

Energy is essential in the economy and in modern society in general. As the main resource and an integral part of almost every production process, energy is important for the use of other resources in the business cycle, the creation of new values, and the fulfillment of needs. Thus, energy or the energy sector has a dual function in the economy: energy production (output) is an essential sector of the economy, while its participation in economic processes affects economic activity (i.e., supports other parts of the economy). An efficient and developed energy sector, with a secure energy supply and stable and reasonable prices of energy resources, enhances the development of economy and the realization of many other economic effects, such as economic competitiveness.

In the production of energy, especially electricity, alongside the problems of affordability of fossil fuels and the dramatic growth in the demand for energy over the last few decades, renewable resources have become an important additional source of energy and further enhance the functioning of the (electrical) energy sector. Renewable energy refers to all energy resources that are naturally replenished at a rate that is equal to or faster than the rate of their consumption or permanent resources that
REVIEW PAPER

RECEIVED: NOVEMBER 2016

REVISED: MARCH 2017

ACCEPTED: APRIL 2017

DOI: 10.1515/ngoe-2017-0012

UDK: 330.34:620.97

JEL: D24, Q42, 013

Citation: Maradin, D., Cerović, L., \& Mjeda, T. (2017). Economic Effects of Renewable Energy Technologies. Naše gospodarstvo/Our Economy, 63(2), 49-59. DOI: 10.1515/ngoe-2017-0012

\section{NG OE}

NAŠE GOSPODARSTVO OUR ECONOMY

\begin{tabular}{l|l|l} 
Vol. 63 & No. 2 & 2017
\end{tabular}

pp. $49-59$ 
are available in nature in abundance (van Vliet, 2012). Renewable resources include solar energy, wind energy, hydropower, energy produced from biomass, geothermal energy, and ocean energy, which includes wave power, tidal energy and ocean currents (Armstrong, Hamrin, 2000). Renewable resources are inexhaustible sources of energy; this means that, although they are consumed in the process of energy conversion, their amount is only temporarily exhausted (i.e., they can always be replaced or restored) (Labudović et al., 2002). The use of renewable energy resources preserves the environment and contributes to the environmental aspect of sustainability. Renewable energy produces little or no waste (resulting in minimal impact on the environment) and allows the use of limited fossil fuels in the future. This is one of the major advantages of the rising investments in the renewable resources technology and its application. It must be pointed out that, alongside the production of electricity, renewable energy technologies play a significant role in the production of heat energy as well.

Therefore, the purpose of this research is to analyse both the positive and the negative economic effects of investing in various renewable technologies, as well as to confirm, by means of the energy-economy model, the benefit such technologies have in boosting the economy.

\section{Literature Review of "Green" Economy}

Analyzing the economic influence of renewable energy technologies (i.e., investments and their use), the literature underlines the direct and indirect benefits of including renewables in the economy.

It is pointed out by Nanda (2015) that investments in the renewable energy sector can stimulate high capital spending flow through the economy and, consequently, can stimulate direct and indirect growth in other related sectors. Clearly, such direct and indirect economic growth in other sectors promotes employment as well (Nanda et al., 2015). Omri, Chtourou and Bazin (2015) argue that the global economic crisis of 2007-2008 was essentially an opportunity to accelerate the spread of renewable energy technologies and that the renewable energy sector plays a crucial role on the path towards a "green" recovery. Furthermore, many international institutions emphasize the need for a "green" recovery, a "green" growth, or a "green new deal", which consists of strategies for economic recovery and environmental protection (cf. OECD, 2009, 2011b, 2011c; UNEP, 2009, 2011; the World Bank, 2012). Technological breakthroughs or innovations are vital in accomplishing this "green" growth. The supports in the form of "green" incentives are specifically pointed out (e.g., investment subsidies, low-interest loans, tax deductions, etc.), and are allocated to renewable energy, energy efficiency, smart power grid, transport, and other clean energy technologies. These grants and other strategies, initiatives, measures and activities have been undertaken by various international organizations, European Union bodies and government bodies at different political levels in order to ensure economic growth and sustainable development (i.e., deployment towards a "greener" economy) (cf. Sedlacko \& Gjoksi, 2009). The "green” economy initiative is not a replacement for sustainable development but, rather, a path to its achievement at the national, regional and global levels (Omri, Chtourou, \& Bazin, 2015).

"Green" policies can contribute to growth through four effects (World Bank, 2012): an input effect (increasing production factors), an efficiency effect (bringing production closer to the production possibility frontier), a stimulus effect (stimulating the economy in times of crisis), and an innovation effect (accelerating development and the adoption and dissemination of renewable energy technologies). Taking into account the economic effects of renewable energy technologies, great importance is given to the innovation effect, which can be illustrated through investments in $R \& D$, for instance, on photovoltaic power motivated by the desire to mitigate greenhouse gas emissions. Success could make photovoltaics competitive with fossil fuels, increase the supply of electric power, and reduce the cost of providing electric power to remote off-grid communities. "Green” innovation is one of the most significant factors in the efficient functioning and application of renewable energy technologies, and it undoubtedly plays a dominant role in the growth and development of a "green" economy. According to the World Bank (2012), "green” innovation is the creation, development and commercialization of new ways to solve environmental and economic problems through improvements in technology, with a wide interpretation of technology as encompassing product, process, organizational, and marketing improvements. Thereby, "green” innovation includes both "new-to-the-world" innovations and "new-to-the-firm" innovations, also known as absorption, which covers the diffusion (both across and within countries), adoption, adaptation (to local contexts), and use of "green” technologies. “Green” innovation, R\&D investments and deployment of renewable energy may be viewed as an important driver in the shaping of economic systems, especially in a "green" growth concept (EEA, 2014).

Creating and increasing employment emerges as a crucial economic and social factor of the development of renewable energy technologies. Alongside continued growth in energy demand and progressive decrease in renewable energy costs and climate change, Omri, Chtourou and Bazin (2015) stress employment creation as a driving force in the development of the renewable energy market. It is estimated that 
8.1 million people were employed in the global renewable energy sector, directly and indirectly, in 2015, at an annual rate of 5\% (IRENA, 2016). The solar photovoltaic industry was the largest renewable energy employer, with 2.8 million jobs worldwide, while the wind power sector recorded a record year of growth. An additional 1.3 million people were employed in large hydropower plants, although, in theory, they are not referred to as "newer" renewable energy sources due to their harmful environmental impact and degradation of the natural ecosystem. While the growth in jobs dropped from a $5 \%$ rate compared to previous years, the total number of jobs in renewables worldwide continued to rise, which is in stark contrast with depressed labor markets in the broader energy sector (IRENA, 2016). An EU-wide study carried out in 1999 estimated that renewable energy has the potential to create over 900,000 new jobs by 2020, including 515,000 jobs in agriculture and biomass fuel supply. Industry estimates endorse these levels of job creation. Already, a number of countries are achieving high employment levels from renewable energy activities, particularly in the wind energy industry (Ecotec, 2002). This confirms the thesis that renewable energy technologies occupy a crucial role in increasing employment and positively contribute to economic effects in the "green" economy.

Among numerous studies on the effects of renewable energy technologies on employment, the study by Meyer and Sommer (2014), which is based on an evaluation of 23 selected impact studies from peer-reviewed journals, should be highlighted. The authors explore whether there is scientific evidence that transitioning to a low-carbon economy may create net employment effects. Given the heterogeneity of assumptions, the results of the different studies are hardly comparable, although they find that a majority of the investigated scenarios show positive net employment effects.

Even though renewable energy technologies have a strong impact on employment, inducing different types of employment effects (direct, indirect, induced, gross or net), previous studies reached different findings. Besides creating new jobs in the "green" economy, a change of employment is also possible, for example, from conventional energy-related activities to renewable energy technologies, or the shed of certain jobs without alternatives, or redefinition of existing jobs in terms of "green" skills, methods and profiles (Meyer \& Sommer, 2014). Furthermore, depending on the level of activity of a technology life cycle or a plant that exploits a renewable energy source, there are various effects on employment. Despite specific characteristics of each renewable energy technology, they all share a life cycle of five stages (Llera et al., 2010):

1. Research and design;

2. Development and manufacture;

3. Construction and installation;

4. Operation and maintenance or service;

5. Updating and/or dismantling.

In order to adequately show the impact of a power plant/technology life cycle on the quantity and quality of employment, the place and duration of employment, and the indirect development of the "green" economy, the abovementioned five stages are modified into three main phases: (1) technological development, (2) installation/uninstallation of a power plant and (3) operation or managing and maintenance of technological plants. The first two phases (i.e., research and design and development and manufacture) are commonly seen as a separate whole, due to their complementary work areas and identical generated employment. This creates a new starting phase of a life cycle, called technological development. Despite the third and the fifth stage being distant in time (i.e., construction and installation and updating or dismantling), they create a single phase of installation/uninstallation, since there is no difference in terms of the types of activities and characteristics of engaged employment. Activities related to the maintenance of power plant operations comprise the third and the last phase of the life cycle. For example, some of these activities include management and maintenance of a wind energy plant; the collection, supply and logistics of work of a biomass plant; and other activities related to the normal functioning of renewable energy technologies. This division of power plants' life cycle into phases could be useful for determining the need for a strategy that generates employment opportunities in one of the three phases, such as encouraging technological innovation (which increases the

Table 1: Stages of the Life Cycle of the Exploitation of RES and Influence on Employment

\begin{tabular}{lllll} 
Phase & Volume of employment & Location of employment & Duration of employment & Level of specialisation \\
\hline $\begin{array}{l}\text { Technological } \\
\text { development }\end{array}$ & Medium & From foreign to local & Stable & Very high \\
\hline $\begin{array}{l}\text { Installation / } \\
\text { uninstallation }\end{array}$ & High & From local to foreign & Temporary & High \\
\hline $\begin{array}{l}\text { Operation and } \\
\text { maintenance }\end{array}$ & Low & Local & Stable & Medium \\
\hline
\end{tabular}

Source: Llera et al. (2010) 
impact on local employment in the first phase) or vocational training (which reduces the need for foreign engineers and technology installers). The impact of the three aforementioned life cycle phases of renewable energy technology on the previously mentioned elements of employment is shown in Table 1.

Table 1 shows the main characteristics of the elements of employment that appear in all three phases of power plant/ technology operations. The amount of employment is particularly high in the installation/uninstallation phase, due to the workforce needed in the process of construction and installation, modernization and/or dismantling of the power plant. The adverse economic effect in this phase is temporary employment, because once the plant is built or dismantled, there is no more need for such specialized workforce. On the other hand, the management and maintenance of renewable energy power plants does not require much workforce, particularly in the case of the wind power industry. The level of expertise and specialization in the technical maintenance and repair of faulty components does not need to be particularly high, since the case is of mid-level complexity, so this job permanently employs mainly local workforce, which is certainly an advantage in exploiting renewable resources. Every national economy aspires to achieve the phase of technological development, which ensures the greatest economic effects of renewable energy technologies. Although the quantity of employment in this phase is of mid-level complexity, the quality of employment is very high, because many technical and technological achievements and improvements are applied; research and development influence the innovation and so on. The substantial benefit of this phase is permanent employment, as well as technology transfer, wherein foreign workforce is transferred in favor of the local workforce. Taking into consideration this literature overview, the positive effects of renewable energy technologies are confirmed.

\section{Energy-economy Model as a Function of Analyzing the Relationship of Energy and Economy}

In a modern business environment, an energy system does not exist "for itself"; rather, it has to be viewed in the context of the entire economic system, to support the economy in the manufacturing of products and the provision of services, but also as a driver of broader economic processes. The literature cites a large number of different surveys of energy-economy interactions (Energy Modeling Forum, 1977; Manne, Richels, \&Weyant, 1979; Ormerod, 1980; Kavrakoğlu, 1987; DeCarolis, Hunter, \& Sreepathi, 2012). Given the challenges that the modern world faces, energy-economy interactions can be improved and then, for example, energy-economy-environment models (Nakata, 2004; Dong, et al., 2014) or energy-economy-climate models (Turton, 2008; Hedenus, Johansson, Lindgren, 2013) can be discussed. In this study, the energy-economy model shown in Figure 1 is selected as a framework and theoretical starting point in understanding the interaction and the realization of synergies between energy activities and the economy.

Figure 1. Energy-economy model

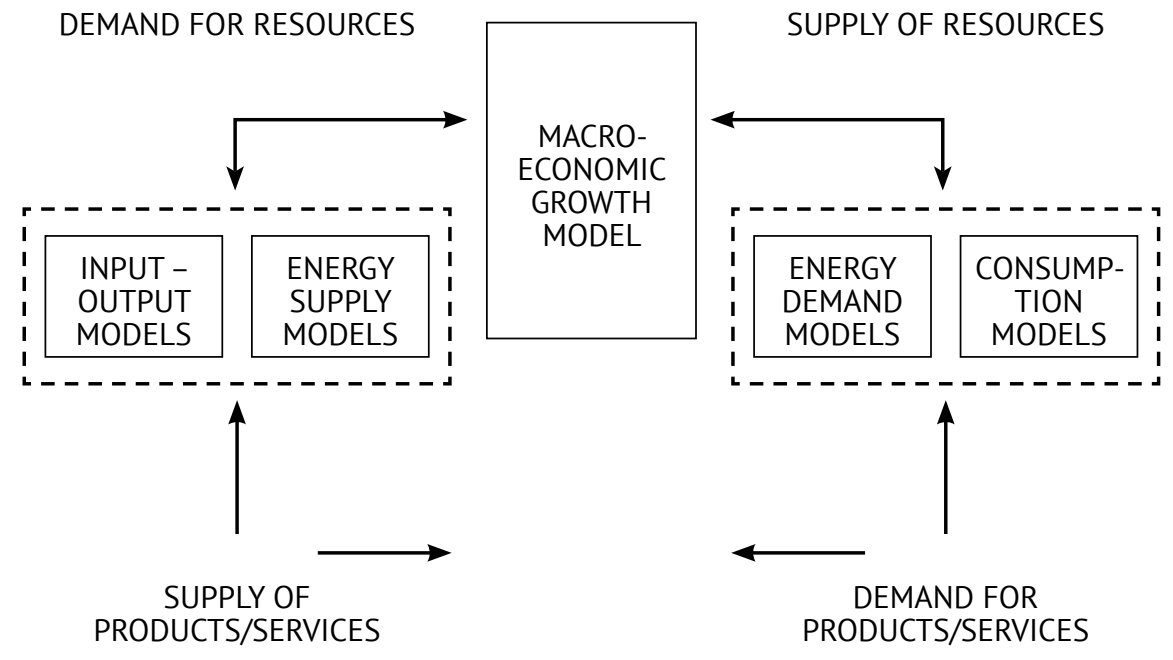

INTEGRATING MECHANISM 
The proposed energy-economy model includes the entire national economy, and its supply side and demand side of both energy and economic perspectives; as such, it points to possible models of economic growth. Also, the energy-economy model is presumed to be a dynamic operator of the system, in the sense that it relates the present with the future states of the system. In the creation of macroeconomic growth, the energy-economy model aims to point out the role of supply and demand of resources (especially energy technologies) on the input side and energy products/services on the output side. The model simultaneously takes into account the requirements of consumers and producers as the main initiators of growth in energy and related industries.

The energy-economy model consists of some basic elements, as follows: a macroeconomic growth model, input-output (or supply) models and energy supply models on the side of producers, and consumption models and energy demand models on the side of consumers. It should be noted that the macroeconomic growth model is the integrating mechanism that brings all other models together through the classical notion of economic equilibrium (supply = demand). Input-output models represent intersectoral flows and producers' behavioral patterns. Energy supply models analyze the impact of new energy technologies and the optimal structure of the energy system, thus making them the most important starting point in generating economic growth driven by energy (due to the subject matter of this paper). While it is necessary to take into account the overall energy-economy model as the basis of the macroeconomic growth, the authors nonetheless emphasize the energy supply models that significantly contribute to economic activities and boosting the economy through the new energy technologies, especially renewable energy technologies. On the demand side, consumption models investigate consumers' behavioral patterns (i.e., allocation of aggregate demand to products and services). Finally, in energy demand models, numerous research questions are analyzed (e.g., energy conservation, price effects, tax and tariff effects, energy efficiency, etc).

Finally, the proposed energy-economy model, as a theoretical model, is considered to be an appropriate framework to accompany the study, particularly due to the overall equilibrium of producers and consumers in meeting the needs for energy/ economic resources/products/services as a way of opening up a real possibility for economic growth. On such foundations of the equilibrium between producers and consumers, with full capacity utilization, or utilization of resources and assets, it is possible to analyze the impact of renewable energy technologies on economic growth and development.

Based on the above discussion, the sequel shows the most important part of this study, which analyzes the positive and negative economic effects of renewable energy technologies.

\section{Positive and Negative Economic Effects of Renewable Energy Technologies}

Although the starting point in the analysis of positive and negative economic effects of renewable energy technologies is the macroeconomic model known as the energy-economy model, in which economic effects are mainly studied at the macro level, it is possible to identify them at the sectoral level, the micro level and the enterprise level.

Firstly, investments and the application of renewable energy technologies contribute significantly to economic growth and development, gradually transforming the economy towards the sustainable "green” economy (OECD, 2011a), which directly confirms the impact of the previously described energy supply models on macroeconomic growth. Economic growth based on "green" technologies creates a new impetus in the creation of new business processes and economic flows, wherein the emphasis is placed on sustainability, economic and energy efficiency, the use of clean technologies, optimal utilization of capacities, both natural and physical, environmental issues, and the like. One of the main advantages of using renewable energy technologies is their sustainability. In promoting renewable energy technologies, the benefits include not only direct economic benefits, like the creation of jobs, but also the establishment of related new businesses. New jobs and business opportunities include research, local manufacture, logistics, maintenance engineers, consultants, business developers and designers, and lawyers, among others. New business opportunities represent an additional supply of goods and services to the economy, in which growth is generated by input-output (or supply) models. In this way, renewable energy technologies certainly foster the development and revitalization of local economies (cf. IEA RETD TCP, 2016). In that sense, renewable energy technologies represent a vital stimulus for local economies, particularly those facing the challenges of economic readjustment or geographic isolation.

Furthermore, the innovation that promotes technical and technological changes in new market structures has been indentified as the most important benefit of renewables (Frankhauser, Sehlleier, \& Stern, 2008). Innovations are, in fact, related to new technologies/technological processes in the energy sector that lead to the improvement of business processes and economic growth driven by the energy supply models. In the same way, considering the long-term period, technological changes and innovation, as well as the gradual development of renewable energy technologies, create the need for qualified workforce, thus directly boosting employment. The creation of new opportunities for investments into "green” energy, research, technological innovation, and, consequently, economic growth, is spurred by, among other things, climate change and environmental protection policies. 
The important role of deliberate policies aimed at motivating energy-technological innovation is underlined (Simas \& Pacca, 2013). The policies should lower institutional and market barriers and remove the limitations for new technologies and markets. One such measure is the so-called energy-based economic development, which integrates economic development and energy policy and planning into a new field of managing national economies. Economic growth based on energy is defined as the process in which decision makers in economic and energy planning and development, government officials and other public authorities, energy regulators, industry and municipal services, their managers and executives, and other market participants tend to increase energy efficiency and/or diversification of energy resources in a way that creates new jobs, maintains employment, and encourages the prosperity of the region (Carley et al., 2001). The essence of the concept of economic growth based on energy lies in fulfilling economic and energy development needs. Thus, the fundamental objectives relate to the increase of energy efficiency, diversification of resources and self-sufficiency, improvement of industry and economic growth and development, development of entrepreneurship, encouragement of technological innovation, increase in the level of employment and training, and so on. Thus, energy-based economic development is closely related to the overall energy-economy model, where the economic and energy potentials are intertwined in the economic development and the creation of new added value. Energy diversification, energy self-sufficiency and the improvement of technological innovation are the factors that develop regional competitiveness and provide opportunities to create new jobs, especially when the focus is on renewables. In that sense, the pioneers in the development of clean "green" technologies have an opportunity to become regional or even global leaders in the industry. The example of Germany must be pointed out here, as this country is the leader in the export of renewable energy technologies (Fankhauser, Sehlleier, \& Stern, 2008; Simas \& Pacca, 2013).

Given that environmentally friendly renewable energy sources in the production of energy function only as an addition to conventional power plants in the energy system, the substantial financial benefit of renewable energy technologies lies in the reduction of fossil fuels that would otherwise be used in conventional power plants to produce the same amount of energy. Moreover, renewable energy technologies reduce imports, especially the import of electricity and fossil energy resources (i.e., fuels for the production of energy). The above causes a reduction in demand for fossil energy resources, raising the possibility of their use in the future together with the use of inexhaustible sources of renewable energy (result of energy supply models). This directly influences the improvement of the balance of trade of individual national economies.
The application of renewable energy technologies in rural areas, especially in underdeveloped rural areas, could foster their economic growth and civilization's need for energy in general. This environment is particularly suitable for investments in renewable energy technologies, mostly due to the lack of alternative development projects in that area, appropriate spatial and temporal conditions and the opportunities for employment of local people coming from the assumed high unemployment rate, and so on. In this way, in addition to being an additional source of energy in the conventional electro-industry, renewable energy resources provide much-needed electricity in areas where the electrical grid is underdeveloped or does not exist, such as remote villages or islands. If based on coherent policies, renewable energy technologies could be considered a cost-effective tool in reducing electricity shortages. Not being connected to the national power grid, separate power systems using hybrid systems of renewable energy technologies are installed in areas where grid extension is technically and/or economically unfeasible, such as remote or inaccessible areas (Sreeraj, Chatterjee, \& Bandyopadhyay, 2010). Likewise, the extension of the power grid in rural areas is not economically viable due to the high costs of electricity distribution and the related energy losses in the transmission network. Therefore, electricity off the grid, produced in the hybrid system of renewable energy resources (i.e., in a power system with the ability to store energy or produce it from multiple renewable resources) enables the process of rural electrification and brings benefits for the community, thus being a cost-appropriate strategy of electricity usage (Borhanazad et al., 2013). It is of exceptional importance to consumers that such hybrid systems of renewable energy technologies are price acceptable, or cost efficient, with continuous consumption of sufficient amounts of energy. The conclusion is that economic growth and development with (energy) supply models can be achieved through models of energy demand, as shown in the example of renewable energy technologies in rural areas.

Both directly and indirectly, renewable energy technologies affect sectoral activities as well. Although energy production, or electricity generation, is considered the primary purpose of renewable energy technologies, this is only one segment of the positive economic effects of renewable energy technologies, which need further elaboration. In the total production of "green” electricity, renewable resources hold a negligible share (unlike big conventional power plants that can have a few dozens to several hundred MW of installed capacity and generate huge amounts of energy). Taking into account only "new" renewable energy resources, the world production of "green" electricity is as low as $2 \%$. If heat energy generated from "modern” biomass, solar and geothermal sources is added to this, the share of energy rises to $6 \%$ (REN21, 2013). In the production of energy, 
renewable energy technologies ensure a secure supply in the energy sector, making the entire energy system sustainable. The previous discussion results in a conclusion that renewable energy technologies have a far-reaching and significant impact on the development of related branches of industry, primarily the manufacturing industry. The manufacturing industry has been identified as the crucial end-use sector that must be engaged in order to achieve a higher share of renewable energy technologies (IRENA, 2015). Moreover, the share of renewable energy is likely to rise, since it has a great potential to substitute fossil-fuel-based energy in the production of heat energy and feedstock used in material production. The potential to substitute fossil-fuel-based energy with renewable energy technologies ranges from $8 \%$ (in the iron and steel sector) to as high as $30 \%$ (in the non-metallic minerals sector) for different energy-intensive sectors (IRENA, 2014). Currently, among the renewable technology options, biomass offers the greatest potential to provide high-temperature process heat for energy-intensive sectors and to replace fossil fuels that are used for chemical and polymer production. Furthermore, biomass can also be easily integrated into existing plants for cement or brick production, as well as into the production processes of iron and steel making. To a certain extent, solar thermal systems could also provide high-temperature heat, but more research and development is required to make those technologies available. Solar thermal systems is technically and economically feasible in the small-scale plants and less energy-intensive industries, like the textile and food sectors, but the high initial capital costs and low deployment rates make the use of this technology impractical. In addition to the manufacturing industry, renewable energy technologies are closely related to the construction sector, as well as agriculture and forestry in the case of biomass energy, while an indirect influence is seen in the financial sector and the insurance sector.

At the microeconomic level, the application of renewable energy technologies increases productivity not only in the energy sector but also in all related activities in which renewable technologies are developed. Productivity is closely related to, and contributes to, the strengthening of entrepreneurship and the creation of competitive market relations. It has been found small and medium-sized enterprises, in more than $90 \%$ of all manufacturing businesses, play a crucial role in increasing the deployment rate of renewable energy technologies, providing local manufacturing opportunities and stimulating cost reductions (IRENA, 2014). This leads to the improvement of technical and technological development, with an increase in technical efficiency as well as economic efficiency in terms of management of the organizational unit.

In addition to the multiple benefits of renewable energy technologies, there are also certain disadvantages and limitations of their investment and application. The research and development of renewable energy technologies demands considerable financial resources. With the exception of highly developed countries, public authorities are unable to provide the necessary funds to develop the industry and the market of renewable resources. On the other hand, if there are insufficient investments into renewable energy technologies, these will need to be imported (Rader \& Norgaard, 1996), as is the case in Croatia, for example, where most investments are made in the development of foreign economies. The serious disadvantage of greater use of renewable energy technologies is certainly their relatively high cost of electricity production. The literature highlights the higher cost of construction of renewable energy plants compared to fossil fuel plants. However, if the cost of $\mathrm{CO} 2$ emission trading is added to the total costs, it becomes clear that renewable energy technologies are cost-competitive with conventional power plants (cf. Tarjanne \& Kivistö, 2008). Furthermore, renewable energy resources, such as biomass, also increase food prices, because more and more crops are produced as biofuels, which leads to a shortage of food in the market and consequently increased food prices. One of the major limitations of the daily use of renewable energy technologies is the reliability of the renewable energy supply. Because of their natural characteristics, renewable sources depend entirely on the geographical deployment and weather conditions; therefore, the volatility and unpredictability of renewable sources represent a significant restriction and difficulty in the production of energy. Due to the intermittent characteristics of renewable energy resources, assessing the reliability of power systems with renewables is challenging and has been widely studied for the past several decades (Zhou, Jin, \& Fan, 2016). This limitation may be reduced by quality planning and carefully choosing the location for the renewable energy technology, as well as by appropriate measurements and preparation of environmental studies. Also, due to large daily fluctuations in the availability of renewable energy sources based on which energy is created, it is necessary to consider possibilities of integrating the renewable energy in the energy system. The energy system grid must always include sufficient reserves in the form of available installed capacity of power plants that can eliminate disadvantages that occur when certain renewable energy sources are not available.

Figure 2 shows a clear summary of the overall positive and negative economic effects of the application of the renewable energy technologies that were presented in this section.

Based on the above discussion, it can be concluded that renewable energy technologies have numerous benefits but also certain disadvantages in generating additional amounts of energy, and their application should primarily be considered in the context of the improvement of the energy sector and the development of national economies. 
Figure 2. Positive and negative economic effects of renewable energy technologies

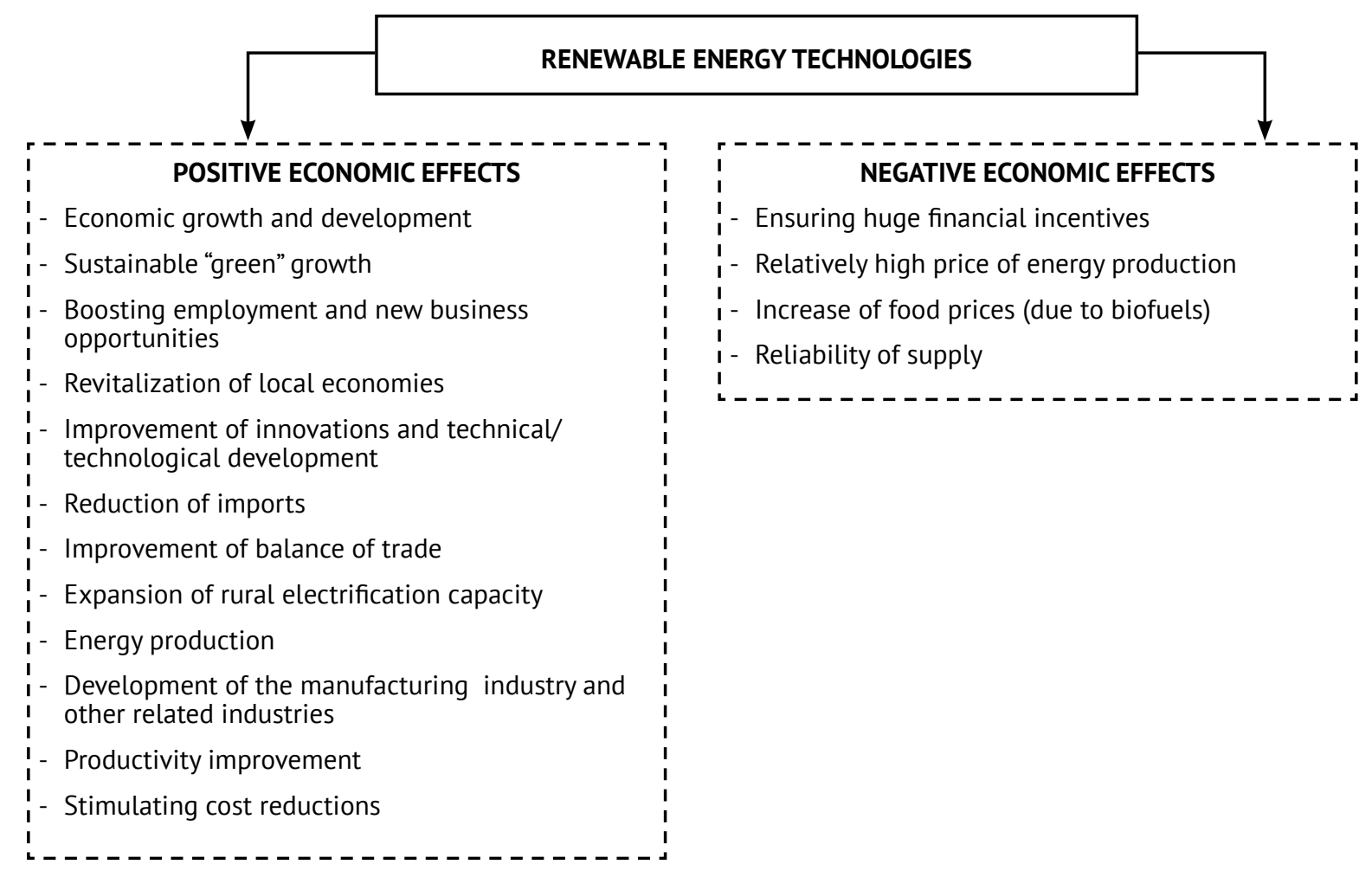

\section{Conclusion}

This paper presents a number of positive and negative effects of investments and use of renewable energy technologies. Economic effects are analyzed at the macro level, based on the energy-economy model, as well as at the sectoral level and at the micro level. The fact that renewable energy technologies stimulate economic growth and sustainable development (i.e., deployment towards a "greener" economy) is identified as the most significant positive effect. In this way, renewable energy technologies directly influence the creation of "green" jobs and boost employment. Many authors analyze employment effects of renewable energy technologies, and nearly all studies conclude that there are positive net employment effects. In addition to multiple positive aspects of using renewable energy technologies, there are negative aspects as well, such as the relatively high cost of production of electricity from renewable energy resources, or the lack of substantial financial resources with the aim of promoting research and development on renewable energy technologies.

Considering primarily the economic benefits, but also the environmental and social benefits, of renewable energy technologies and their role in the growing energy security issues, the governments of certain national economies have issued many policies to boost the deployment of renewable energy. The role of public authorities is emphasized in creating a "favorable climate" for renewable energy technologies. Also, economic growth and development resulting from the application of renewable energy technologies depends not only on economic policy measures at the national level but also at sub-national and local levels, as well as on the accompanying institutional framework and generally accepted social consensus on renewable energy technologies. Therefore, there is a need to analyze concrete economic policy measures in further research, as well as a need for renewable energy incentive programs to contribute to the achievement of maximum usability of renewable energy technologies, with the aim of further growth and development of the national economy. In addition, there is also a possibility in future research for further adaptation and extension of the applied general energy-economy model in relation to renewable energy technologies, as well as to base conclusions regarding the economic effects of these technologies on a quantitative analysis of real-life data. 


\section{References}

Armstrong, A. J., \& Hamrin, J. (2000). The renewable energy policy manual. United States Export Council for Renewable Energy, Washington. Retrieved from https://www.oas.org/dsd/publications/Unit/oea79e/oea79e.pdf

Borhanazad, H., Mekhilef, S., Saidur, R., \& Boroumandjazi, G. (2013). Potential application of renewable energy for rural electrification in Malaysia. Renewable Energy, 59, 210-219. https://doi.org/10.1016/j.renene.2013.03.039

Carley, S. et al. (2011). Energy-based economic development. Renewable and Sustainable Energy Reviews, 15(1), 282-295. https://doi. org/10.1016/j.rser.2010.08.006

DeCarolis, J. F., Hunter, K., \& Sreepathi, S. (2012). The case for repeatable analysis with energy economy optimization models. Energy Economics, 34(6), 1845-1853. https://doi.org/10.1016/j.eneco.2012.07.004

Dong, J., Chi, Y., Zou, D., Fu, C., Huang, Q., \& Ni, M. (2014). Energy-environment-economy assessment of waste management systems from a life cycle perspective: Model development and case study. Applied Energy, 114, 400-408. https://doi.org/10.1016/j. apenergy.2013.09.037

Ecotec (2002). Renewable energy sector in the EU: Its employment and export potential. A Final Report to DG Environment, Birmingham. Retrieved from http:// ec.europa.eu/environment/enveco/eco_industry/pdf/ecotec_renewable_energy.pdf

EEA (2014). Energy support measures and their impact on innovation in the renewable energy sector in Europe. European Environment Agency, Technical report, No. 21, Copenhagen. Retrieved from http://www.eea.europa.eu/publications/energy-support-measures

Energy Modeling Forum (1977). Energy and the economy. EMF Report 1, Volumes 1 and 2, Stanford. Retrieved from https://web.stanford. edu/group/emf-research/docs/ emf1/emf1vol1+2.pdf

Fankhauser, S., Sehlleier, F., \& Stern, N.(2008). Climate change, innovation and jobs. Climate Policy, 8(4), 421-429.https://doi.org/10.3763/ cpol.2008.0513

Hedenus, F., Johansson, D., \& Lindgren, K. (2013). A critical assessment of Energy-economy-climate models for policy analysis. Journal of Applied Economics and Business Research, 3(2), 118-132.

IEA RETD TCP (2016). Revitalisation of local economy by development of renewable energy: Good practices and case studies (REvLOCAL). IEA Renewable Energy Technology Deployment Technology Collaboration Programme (IEA RETD TCP), Utrecht. Retrieved from http://iea-retd.org/documents/2016/09/revlocal-summary-report.pdf

IRENA (2016). Renewable energy and jobs - Annual review 2016. IRENA, Abu Dhabi. Retrieved from http://www.irena.org/DocumentDownloads/Publications/IRENA_RE_Jobs_Annual_Review_2016.pdf

IRENA (2015). Renewable energy options for the industry sector: Global and regional potential until 2030 - A background paper to "Renewable energy in manufacturing". IRENA, Abu Dhabi. Retrieved from http://www.irena.org/remap/ IRENA_RE_Potential_for_ Industry_BP_2015.pdf

IRENA (2014). Renewable energy in manufacturing - A technology roadmap for REmap 2030. IRENA, Abu Dhabi. Retrieved from https:// www.irena.org/remap/ IRENA_REmap\%202030\%20Renewable-Energy-in-Manufacturing.pdf

Kavrakoğlu, İ. (1987). Energy policy: modelling and analysis. Mathematical Modelling, 9(9), 659-667. https://doi.org/10.1016/02700255(87)90467-2

Labudović, B. et al. (2002). Obnovljivi izvori energije. Energetika marketing, Zagreb.

Llera, S. E. et al. (2010). Local impact of renewables on employment:Assessment methodology and case study. Renewable and Sustainable Energy Reviews, 14(2), 679-690. https://doi.org/10.1016/j.rser.2009.10.017

Manne, A. S., Richels, R. G., \& Weyant, J. P. (1979). Feature article - Energy policy modeling: A survey. Operations Research, 27(1), 1-36. https://doi.org/10.1287/opre.27.1.1

Meyer, I., \& Sommer, M. W. (2014). Employment effects of renewable energy supply - A meta analysis. WWW for Europe Policy Paper series, No.12. Retrieved from http://www.wifo.ac.at/jart/prj3/wifo/resources/person_dokument/person_dokument.jart?publikationsid=47225\&mime_type=application/pdf

Nakata, T. (2004). Energy-economic models and the environment. Progress in Energy and Combustion Science, 30(4), 417-475. https://doi. org/10.1016/j.pecs.2004.03.001

Nanda, N. et al. (2015). Assessing economic, social and environmental benefits of renewable energy in India. Policy Analysis on Growth and Employment, The Energy and Resources Institute, New Delhi. Retrieved from https://www.pep-net.org/sites/pep-net.org/files/ typo3doc/pdf/files_events/2015_kenya_conf/MPIA_12806.pdf

OECD (2011a). Energy. OECD Green Growth Studies, Paris. Retrieved from https://www.oecd.org/greengrowth/greening-energy/49157219.pdf

OECD (2011b). Towards green growth: A summary for policy makers. OECD, Paris. Retrieved from http://www.oecd.org/ greengrowth/48012345.pdf

OECD (2011c). Towards green growth: Monitoring progress. OECD, Paris. Retrieved from http://www.oecd.org/greengrowth/48224574.pdf

OECD (2009). Green growth: Overcoming the crisis and beyond. OECD, Paris. Retrieved from https://www.oecd.org/env/43176103.pdf

Omri, E., Chtourou, N., \& Bazin, D. (2015). Rethinking the green recovery through renewable energy expansion. International Journal of Sustainable Development, 18(1/2), 59-76. https://doi.org/10.1504/IJSD.2015.066787

Ormerod, R. J. (1980). Energy models for decision making. European Journal of Operational Research, 5, 366-377. https://doi. org/10.1016/0377-2217(80)90123-X 
Rader, N. A., Norgaard, R. B. (1996). Efficiency and sustainability in restructured electricity markets: The renewables portfolio standard. The Electricity Journal, 9(6), 37-49. https://doi.org/10.1016/S1040-6190(96)80262-4

REN21 (2013). Renewables 2013 Global Status Report, Renewable energy policy network for the $21^{\text {st }}$ century. REN21 Secretariat, Paris. Retrieved from http://www.ren21.net/Portals/0/documents/Resources/GSR/2013/GSR2013_lowres.pdf

Samouilidis, J.-E., \& Mitropoulos, C.S. (1982). Energy-economy models: A survey. European Journal of Operational Research, 11(3), $222-232$. https://doi.org/10.1016/0377-2217(82)90246-6

Sedlacko, M., \& Gjoksi, N. (2009). Sustainable development and economic growth: Overview and reflections on initiatives in Europe and beyond. European Sustainable Development Network, ESDN Quarterly Report. Retrieved from http://www.sd-network.eu/ quarterly\%20reports/report\%20files/pdf/2009-December-Sustainable_development_and_economic_growth.pdf

Simas, M., \& Pacca, S. (2013). Socio-economic benefits of wind power in Brazil. Journal of Sustainable Development of Energy, Water and Environment Systems, 1(1), 27-40. https://doi.org/10.13044/j.sdewes.2013.01.0003

Sreeraj, E. S., Chatterjee, K., \& Bandyopadhyay, S. (2010). Design of isolated renewable hybrid power systems. Solar Energy, 84(7), 1124-1136. https://doi.org/10.1016/j.solener.2010.03.017

Tarjanne, R., \& Kivistö, A. (2008). Comparison of electricity generation costs. Lappeenranta University of Technology, Faculty of Technology, Department of Energy and Environmental Technology, Research Report EN A-56. Retrieved from http://www.doria.fi/ bitstream/handle/10024/39685/isbn9789522145888.pdf?sequence=1

Turton, H. (2008). ECLIPSE: An integrated energy-economy model for climate policy and scenario analysis. Energy, 33(12), 1754-1769. https://doi.org/10.1016/j.energy.2008.07.008

United Nations Environment Programme (UNEP) (2011). Towards a green economy: Pathways to sustainable development and poverty eradication - A synthesis for policy makers. Retrieved from http://www.unep.org/publications/contents/pub_details_search. asp? ID $=4188$

United Nations Environment Programme (UNEP) (2009). Global green new deal: Policy brief. Retrieved from http://www.unep.org/ pdf/A_Global_Green_New_Deal_Policy_Brief.pdf

Van Vliet, B. (2012). Renewable resources. In D. Southerton (Ed.), Encyclopedia of Consumer Culture (pp. 1212-1214). Thousand Oaks, CA: SAGE Publications.

World Bank (2012). Inclusive green growth, the pathway to sustainable development. Retrieved from http://siteresources.worldbank. org/EXTSDNET/ Resources/Inclusive_Green_Growth_May_2012.pdf

Zhou, P., Jin, R. Y., \& Fan, L. W. (2016). Reliability and economic evaluation of power system with renewables: A review. Renewable and Sustainable Energy Reviews, 58, 537-547. https://doi.org/10.1016/j.rser.2015.12.344

\section{Authors}

Dario Maradin, Ph.D., is an assistant professor at the Faculty of Economics, University of Rijeka, Croatia. He is involved in courses on Microeconomics at the undergraduate and graduate levels in both Croatian and English. His research area is energy economics, especially renewable energy sources and the economic efficiency of various types of power plants. $\mathrm{He}$ is the author/coauthor a number of scientific articles in various Croatian and international journals and conference proceedings.

Ljerka Cerović, Ph.D., is a full professor at the Faculty of Economics, University of Rijeka, Croatia. She teaches Microeconomics and related courses at the undergraduate, graduate, and postgraduate levels and is head of the Department for Theoretical Economics. She has participated in numerous conferences in Croatia and abroad and has published more than 70 scientific/ expert papers in national/international publications. She is a leader/member of scientific-expert committees, editorial and review boards, educational programs and higher-education associations.

Trina Mjeda received her MEcon degree from the Faculty of Economics, University of Zagreb, Croatia in 2008. Currently, she is working towards her Ph.D. at the Faculty of Economics at the University of Rijeka in Croatia. Since 2012, she has been working as an assistant at the University North in Koprivnica and Varaždin, with her scientific and educational field of interests in economic theory. She is fluent in English and also speaks German, Spanish and Albanian. 


\section{Ekonomski učinki tehnologij obnovljive energije}

\section{Izvleček}

Rezultat hitro razvijajočega se gospodarstva je pogostejša uporaba tehnologij obnovljive energije. Po drugi strani pa proizvodnja in uporaba obnovljive energije spodbujata razvoj novih tehnologij, kar ustvarja mnoge nove priložnosti za posameznike, zainteresirane za podjetništvo, in posledično za gospodarstvo nasploh. Tehnologije obnovljive energije imajo multiplikativni učinek na spodbujanje ekonomije in razvoja ne samo energetskega sektorja, temveč tudi vseh podpornih aktivnosti takšne industrije. Namen te raziskave je analizirati pozitivne in negativne ekonomske učinke investiranja v različne obnovljive tehnologije ter z modelom ekonomije energije potrditi koristi takšnih tehnologij pri krepitvi gospodarstva.

Ključne besede: viri obnovljive energije, nove tehnologije, krepitev gospodarstva. 